\title{
Effects of chronic heat stress on granulosa cell apoptosis and follicular atresia in mouse ovary
}

Jieyun $\mathrm{Li}^{1 \dagger}$, Hui Gao ${ }^{2 \dagger}$, Zhen Tian', Yi Wu', Yingzheng Wang ${ }^{2}$, Yuan Fang ${ }^{1}$, Lu Lin', Ying Han', Shuaishuai Wu', IhteshamUl Haq ${ }^{1}$ and Shenming Zeng ${ }^{1 *}$

\begin{abstract}
Background: Heat stress is known to alter follicular dynamics and granulosa cell function and may contribute to the diminished reproductive efficiency commonly observed in mammals during the summer. Although several investigators have studied heat-induced ovarian injury, few reports have focused on the effects of chronic heat stress on ovarian function and the molecular mechanisms through which it induces ovarian injury.

Methods: In Exp. 1, 48 female mice were assigned to a control or heat-stressed treatment. After exposure to a constant temperature of $25^{\circ} \mathrm{C}$ for $7,14,21$ or $28 \mathrm{~d}(n=6)$ or to $42{ }^{\circ} \mathrm{C}$ for $3 \mathrm{~h}$ per $\mathrm{d}$ for $7,14,21$ or $28 \mathrm{~d}(n=6)$, the mice were euthanized and their ovaries were analyzed for follicular atresia, granulosa cell apoptosis, changes in the abundance of HSP70 protein and serum concentrations of estradiol. In Exp. 2, the expression of HSP70 and aromatase was quantified in antral follicles cultured in vitro at 37 or $42{ }^{\circ} \mathrm{C}$ for $24 \mathrm{~h}$. In Exp. 3, granulosa cells from ovaries maintained at 37 or $41{ }^{\circ} \mathrm{C}$ for $2 \mathrm{~h}$ were analyzed for their expression of HSP70, Bim, caspase-3 and cleaved caspase-3.

Results: In Exp. 1, body weight and food intake of heat-stressed mice decreased $(P<0.05)$ compared with control mice while the concentration of estradiol in serum was lower $(P<0.05)$ in heat-stressed mice than in control mice. Compared with control mice, the percentage of atretic follicles and the number of antral follicles with severe apoptotic signals were increased $(P<0.05)$ after $21 \mathrm{~d}$ of heat-stressed treatment. HSP70 protein was more abundant $(P<0.05)$ in heat-stressed mice than control mice. In Exp. 2, heat stress increased HSP70 and decreased aromatase proteins $(P<0.05)$ in antral follicles. In Exp. 3, TUNEL-positive granulosa cells from heat-stressed ovaries were observed concomitant with a significant increase in HSP70, Bim and cleaved caspase-3 protein.

Conclusion: Heat-stress in mice decrease estradiol in serum and aromatase in antral follicles but increased number of atretic follicles and granulosa cell undergoing apoptosis which may explain the decreased fertility commonly observed in heat-stressed animals.
\end{abstract}

Keywords: Apoptosis, Atresia, Follicle, Granulosa cells, Heat stress, Mice

\footnotetext{
* Correspondence: zengshenming@gmail.com

${ }^{\dagger}$ Equal contributors

'Laboratory of Animal Embryonic Biotechnology; National Engineering

Laboratory for Animal Breeding; Key Laboratory of Animal Genetics,

Breeding, and Reproduction of the Ministry of Agriculture, College of Animal

Science and Technology, China Agricultural University, Beijing 100193, China

Full list of author information is available at the end of the article
} 


\section{Background}

Heat stress is known to alter follicular dynamics [1, 2], steroidogenic ability [1, 3], granulosa cell function [3, 4] and oocyte maturation $[5,6]$ and can contribute to diminished reproductive efficiency commonly observed in mammals during the summer. One of the best characterized responses of mammals to elevated temperatures is that of the so-called heat shock proteins (HSP) [7]. HSPs act as molecular chaperones, assisting in the folding, assembly and disassembly of other proteins [8]. Although a number of HSPs are induced by diverse environmental stressors, one particular family of stress proteins, namely the HSP70s, comprise the major class of proteins induced by elevated temperatures [9].

Estradiol is important in the maintenance of ovarian function $[10,11]$. It regulates follicle development and ovarian atresia, inhibits granulosa cell apoptosis and promotes the division and growth of granulosa cells $[12,13]$. The estradiol levels in follicles have been shown to be significantly decreased by heat-stress in goats [1] and cattle [14]. Heat stress also decreased estradiol secretion in primary cultures of granulosa cells [15]. However, the effects of chronic heat stress on the concentration of estradiol in blood have rarely been investigated. Granulosa cells are critical for normal ovarian function and synthesize an array of factors required for follicle development [16, 17]. Furthermore, the growth, differentiation, and maturation of oocytes are dependent upon proliferation and differentiation of granulosa cells [18]. Follicular cells in atretic follicles are normally eliminated by apoptosis [19]. Thus, a shift in the balance of the signaling pathway between granulosa cell survival and death might alter the fate of ovarian follicles [20, 21]. Although heat stress increases the susceptibility of rat granulosa cells to apoptosis [3], and heat stress impairs granulosa cell function in mice by diminishing steroid production and inducing apoptosis [15], it has not been determined if chronic heat stress affects granulosa cell apoptosis. Two important protein families that regulate apoptosis are those of the Caspase family and the Bcl-2 family [22]. Caspases participate in two major apoptotic cascades namely the death receptor pathway and the mitochondrial pathway [23, 24]. Moreover, They are the final executor of cell apoptosis and the common downstream end-point of several converging apoptotic pathways $[23,24]$. Caspase- 3 generally exists in the cytoplasm as a $32-\mathrm{kDa}$ zymogen that is activated at the early stages of apoptosis. The activation of caspase- 3 to either one of its catalytically active p17- or p12subunits has been demonstrated in different cells undergoing apoptosis. Furthermore, several hormones and growth factors regulate granulosa cell apoptosis by inhibiting or activating caspase activity. However, the role of caspase in heat stress-induced granulosa cell apoptosis is unknown.
The Bcl-2 protein family is another major regulator of apoptosis [25]. The balance between pro- and antiapoptotic Bcl-2 members is believed to be responsible for the regulation of granulosa cell apoptosis and survival [26]. Furthermore, Bim (also known as Bcl-2related ovarian death gene) promotes apoptosis by binding with anti-apoptotic Bcl-2 family members thereby inducing mitochondrial release of cytochrome c, which subsequently activates caspase-9, caspase-3 and death effector molecules [27]. Bim proteins were also identified in granulosa cells of primordial, primary, secondary, and mature follicles in the mouse [28]. The cellular functions and the relative contribution of Bim to heat stress-induced apoptosis of granulosa cells have not been elucidated.

Although several investigators have studied heatinduced ovarian injury, few reports have focused on the effects of chronic heat stress on ovarian function and the molecular mechanisms through which heat stress induces ovarian injury. Therefore, this study was designed to investigate the effects of chronic heat stress on follicular atresia, granulosa cell apoptosis and the molecular mechanism of heat-induced ovarian injury.

\section{Methods}

Exp. 1 was conducted in the Peking University Laboratory Animal Centre (Peking University, Beijing, China). The protocol for Exp. 1 was reviewed and approved by the Institutional Animal Care and Use Committee at Peking University (Beijing, China). The animal experimentation procedures for Exp. 2 and 3 were approved by the Institutional Animal Care and Use Committee at China Agricultural University (Beijing, China).

\section{Animals and treatments}

Forty-eight, 3-weeks-old female ICR mice were obtained from Vital River Laboratories (Beijing, China). The animals were housed in individual cages in a climatecontrolled room at the Peking University Laboratory Animal Center (Beijing, China) under conditions of 12-h light and $12-\mathrm{h}$ dark and $50 \%$ relative humidity. The mice were randomly assigned to either a control or a heat-stressed treatment. After exposure to a constant temperature of $25^{\circ} \mathrm{C}$ for $7,14,21$ or $28 \mathrm{~d}$ (Con $n=6$ ) or to $42{ }^{\circ} \mathrm{C}$ for $3 \mathrm{~h}$ per $\mathrm{d}$ for $7,14,21$ or $28 \mathrm{~d}(\mathrm{HS} n=6)$, the mice were euthanized and their ovaries were analyzed for follicular atresia, granulosa cell apoptosis, changes in the abundance of HSP70 protein and concentrations of estradiol in serum. The body weights and food intake of mice were measured weekly.

\section{Sampling of blood and serum hormone assays}

Mice were euthanized with isoflurane $7,14,21$ or $28 \mathrm{~d}$ after the onset of treatment and blood was collected from 
the orbital venous plexus. Samples were collected into evacuated serum tubes (BD Vacutainer; BD and Co., Franklin Lakes, NJ) containing clot activator for serum. The blood was centrifuged and the supernatants were stored at $-80{ }^{\circ} \mathrm{C}$ until assayed for estradiol. The concentrations of estradiol in serum were measured by a mousespecific radioimmunoassay (RIA) at the Beijing North Institute of Biological Technology (Beijing, China). The sensitivity of the RIA was $4 \mathrm{pg} / \mathrm{mL}$. The inter- and intraassay coefficients of variation for estradiol were 20 and $15 \%$, respectively.

\section{Histological analysis}

Following slaughter, 1 ovary from each mouse was fixed in $4 \%$ paraformaldehyde for $16 \mathrm{~h}$ at $4{ }^{\circ} \mathrm{C}$ followed by processing in paraffin, sectioning, and staining with haematoxylin and eosin. After staining, the follicles were categorized as primordial, primary, secondary, mature, or atretic. Follicles were classified as primordial if they contained an oocyte surrounded by a single layer of flattened follicular cells. They were classified as primary when the flattened cells of the follicles became squamous or cuboidal (the so-called granulosa cells). Follicles were classified as secondary by the presence of a visible follicular antrum. In follicles with a markedly enlarged antrum, the cumulus oophorus was diminished, leaving the free-floating oocyte surrounded by 2 or 3 layers of granulosa cells. After this stage, the follicle bulged outward from the ovary and were classified as mature follicle. Typical interstitial glands and follicles with a shrunken oocyte or with granulosa cells that had begun to disaggregate were categorized as atretic follicles. The total number of antral follicles and atretic follicles per ovary was determined by taking an average of the counts from 3 sections ( 5 sections apart) cut along the long axis of the entire ovary. The percentage of atretic follicles in the antral follicles was calculated.

\section{Detection of apoptotic follicles and granulosa cells}

Apoptosis was analyzed by TUNEL using the In Situ Cell Death Detection Kit according to the manufacturer instructions (Roche Applied Science, Indianapolis, IN, USA). After deparaffinization and rehydration of tissue sections, they were incubated with $20 \mu \mathrm{g} / \mathrm{mL}$ proteinase $\mathrm{K}$ for $15 \mathrm{~min}$ at room temperature, quenched with $3 \%$ $\mathrm{H}_{2} \mathrm{O}_{2}$ in PBS for 10 min to block endogenous peroxidase activity, incubated in a humidified chamber with equilibration buffer for 5 min and treated with terminal deoxynucleotidyltransferase for $1 \mathrm{~h}$ at $37^{\circ} \mathrm{C}$. Negative control slides were incubated as described above in the absence of terminal deoxynucleotidyltransferase. Thereafter, tissue sections were washed three times with PBS, counterstained with $0.5 \mu \mathrm{g} / \mathrm{mL}$ Hoechst 33342 (Sigma-Aldrich, St. Louis, MO, USA) in PBS for $5 \mathrm{~min}$, washed 3 times in PBS, and sealed under cover slips with nail varnish. Slides were examined under a Leica fluorescence microscope (Leica DC 200 digital camera; Leica, Wetzlar, Germany). The total number of antral follicles with weak, intermediate or strong apoptotic signals per ovary was determined by taking an average of the counts from 3 sections (5 sections apart) along the longitudinal axis of the entire ovary.

Granulosa cells were washed 3 times with PBS-PVA (polyvinyl alcohol, $0.1 \%$ ) and then fixed with $4 \%$ paraformaldehyde at room temperature for $1 \mathrm{~h}$. After fixation, the specimens were incubated in $0.1 \%$ sodium citrate containing $0.5 \%$ Triton $\mathrm{X}-100$ at $4{ }^{\circ} \mathrm{C}$ for $1 \mathrm{~h}$, washed three times with PBS-PVA (polyvinyl alcohol, $0.1 \%$ ) and incubated in the dark in TUNEL reaction medium for $1 \mathrm{~h}$ at $37^{\circ} \mathrm{C}$. Granulosa cells in the positive control mice were treated with $100 \mathrm{U}$ DNase $\mathrm{I}$ in $50 \mathrm{mmol} / \mathrm{L}$ Tris $-\mathrm{HCl}$, $10 \mathrm{mmol} / \mathrm{L} \mathrm{MgCl}_{2}$ and $1 \mathrm{mg} / \mathrm{mL}$ bovine serum albumin (BSA, pH 7.5) for $1 \mathrm{~h}$ before the TUNEL reaction. After the reaction, the cells were counter-stained as previously indicated and mounted with cover slips that were supported by 4 columns of Vaseline and paraffin (9:1). The slides were sealed with nail varnish and examined under a Leica fluorescence microscope (Leica DC 200 digital camera; Leica, Wetzlar, Germany). Ten granulosa cells from each treatment were evaluated for apoptosis and the experiment was repeated 3 times.

\section{Protein extraction and Western Blot}

Western Blot was performed as described previously [29]. In brief, ovaries were homogenized in lysis buffer to obtain protein lysates, and protein concentrations were determined using the Bicinchoninic Acid Assay (Vigorous, Beijing, China). Equal amounts of protein $(100 \mu \mathrm{g})$ were loaded and separated by electrophoresis on $7.5 \%$ sodium dodecyl sulfate polyacrylamide gels. Separated proteins were transferred to nitrocellulose membranes (BioTraceNT, Pall Corporation, Ann Arbor, $\mathrm{MI})$. The non-specific binding sites were blocked with $5 \%$ non-fat milk in TBS-T $(10 \mathrm{mmol} / \mathrm{L}$ Tris, $150 \mathrm{mmol} /$ $\mathrm{L} \mathrm{NaCl}$ and $0.1 \%$ Tween 20, pH 7.5) for $1 \mathrm{~h}$ at room temperature. The membranes were then incubated overnight with primary antibodies at $4{ }^{\circ} \mathrm{C}$.

On the following day, the membranes were washed in TBS-T and incubated with secondary antibodies conjugated to horseradish peroxidase (HRP) for $1 \mathrm{~h}$ at room temperature. The primary antibodies used included mouse anti-HSP70 (dilution: 1:2,000; Cat. No: N27F3-4; Stress Gen Biotechnologies Corp., Victoria, BC, Canada), rabbit anti-aromatase (dilution: 1:2,000; Cat. No. A7981; SigmaAldrich, St. Louis, MO, USA), rabbit anti-Bim (dilution: 1:4,000; Cat. No. C34C5; Cell Signaling Technology, Inc., Danvers, Massachusetts, United State), rabbit anti-caspase3 (dilution: 1:100; Cat. No. sc-7148; Santa Cruz 
Biotechnology, Santa Cruz, CA, USA), and rabbit anticleaved caspase-3 (dilution: 1:500; Cat. No. 9661; Cell Signaling Technology, Inc., Beverly, MA, USA). The actin antibody (dilution: 1:2,000) was obtained from Abmart Biotechnology (Shanghai, China). The secondary antibodies were goat anti-mouse IgG antibody-HRP (dilution: 1:5,000; Zymed; San Francisco, CA, USA) and goat anti-rabbit IgGHRP (ZB-5301, dilution: 1:2,000; Zhongshan Biotechnology, Beijing, China). The protein bands were visualized by enhanced Chemiluminescence Detection Reagents (Applygen Technologies Inc., Beijing, China) and captured with XOMAT BT film (Eastman Kodak Company, Rochester, NY, USA). The films were digitized, and densitometric analysis was performed using ImageJ 1.44p software (National Institutes of Health, Bethesda, MD, USA). The relative intensity of the bands was quantified and normalized to the respective loading control.

\section{Granulosa cell collection, culture and treatment}

Granulosa cells were obtained from the ovaries of CD-1 female mice. In brief, pre-pubertal mice at 19-21 d of age were injected intra-peritoneally with $10 \mathrm{U}$ of equine chorionic gonadotrophin to stimulate follicle growth and the mice were sacrificed at 44 to $46 \mathrm{~h}$ after treatment. The ovaries were harvested, washed with sterile PBS and transferred to a culture dish containing $100 \mu \mathrm{L}$ of aMEM medium supplemented with $10 \mathrm{U} / \mathrm{mL}$ recombinant FSH, $3 \mathrm{mg} / \mathrm{mL}$ bovine serum albumin, $1 \mathrm{mg} / \mathrm{mL}$ bovine fetuin, $5 \mu \mathrm{g} / \mathrm{mL}$ insulin, $5 \mu \mathrm{g} / \mathrm{mL}$ transferrin and $5 \mathrm{ng} / \mathrm{mL}$ selenium. Ovarian heat treatment was carried out in either a 37 or $41{ }^{\circ} \mathrm{C}$ waterbath for $2 \mathrm{~h}$, then the ovaries were harvested and washed with sterile PBS and transferred to a culture dish containing M199 medium. A hypodermic needle was used to puncture the large antral follicles to release granulosa cells into the medium. The cumulus-oocyte complex and ovarian tissue were discarded under a stereomicroscope. Thereafter, granulosa cells were pelleted by centrifugation $(10 \mathrm{~min}$ at $500 \times g$ ), washed three times with PBS and cultured in 6-well plates $\left(5 \times 10^{6}\right.$ cells/well) with $2 \mathrm{~mL}$ of DMEM/F12 containing $10 \%$ heat-inactivated fetal bovine serum, 100 $\mathrm{U} / \mathrm{mL}$ penicillin and $50 \mathrm{mg} / \mathrm{mL}$ streptomycin. Cells were incubated in a humidified atmosphere of $5 \% \mathrm{CO}_{2}$ at $37{ }^{\circ} \mathrm{C}$ for $24 \mathrm{~h}$. Upon completion of the experiment, granulosa cells from each treatment were collected for subsequent analysis by Trypan Blue Stain or snap-frozen for subsequent analysis by TUNEL or Western Blot.

\section{Granulosa cell viability assay}

An aliquot $(10 \mu \mathrm{L})$ of granulosa cells (about $5 \times 10^{5}$ cells/ $\mathrm{mL}$ ) was combined with $1 \mu \mathrm{L}$ of $0.4 \%$ Trypan Blue Solution in centrifuge tube, the cells were stained for $3 \mathrm{~min}$ and the cell concentration was determined with a Hemocytometer (Shanghai Qiujing Biochemical Reagent and Instrument
Company, Shanghai, China). Images were captured immediately using a Leica microscope (Leica DC 200 Digital Camera; Leica, Wetzlar, Germany).

\section{Follicle collection, culture and treatment}

Early antral and pre-ovulatory follicles were collected from CD-1 female mice at $16 \mathrm{~d}$ of age as described previously [30]. The dissected ovaries were transferred to a $35-\mathrm{mm}$ Petri dish with 1 or $2 \mathrm{~mL}$ of Maintenance Medium ( $\alpha$ MEM containing $1 \%$ FBS, $50 \mathrm{U} / \mathrm{mL}$ penicillin and $50 \mu \mathrm{g} / \mathrm{mL}$ streptomycin) containing $0.1 \%$ collagenase and $0.1 \%$ DNase, and incubated in an atmosphere of $5 \% \mathrm{CO}_{2}$ at $37{ }^{\circ} \mathrm{C}$ for $15 \mathrm{~min}$. Thereafter, the follicles were washed and transferred to another 35$\mathrm{mm}$ Petri dish with L15 medium containing $1 \%$ FBS, $50 \mathrm{U} / \mathrm{mL}$ penicillin and $50 \mathrm{mg} / \mathrm{mL}$ streptomycin. Follicles were isolated by gently flicking the dish or cutting the follicles away from the entire ovary with two hypodermic needles and early antral and pre-ovulatory follicles were then carefully removed at room temperature. One and $3 \mathrm{~mL}$ of Maintenance Medium was added to the central well and outer ring of a $60 \mathrm{~mm}$ in vitro fertilization (IVF) Petri dish, respectively. Intact follicles were transferred with a pipette to outer ring of the IVF dish, briefly rinsed, and then transferred to the central well. The IVF dish was briefly incubated. Thereafter, follicles were transferred to a 96-well culture plate containing $100 \mu \mathrm{L}$ of $\alpha \mathrm{MEM}$ media supplemented with $10 \mathrm{U} / \mathrm{mL}$ recombinant $\mathrm{FSH}, 3 \mathrm{mg} / \mathrm{mL}$ bovine serum albumin, $1 \mathrm{mg} / \mathrm{mL}$ bovine fetuin, $5 \mu \mathrm{g} / \mathrm{mL}$ insulin, $5 \mu \mathrm{g} / \mathrm{mL}$ transferrin and $5 \mathrm{ng} / \mathrm{mL}$ selenium. The follicles were incubated in a humidified atmosphere of $5 \%$ $\mathrm{CO}_{2}$ at $37{ }^{\circ} \mathrm{C}$ or $42{ }^{\circ} \mathrm{C}$ for $24 \mathrm{~h}$, and then collected and snap-frozen for subsequent analysis by Western Blot to detect the abundance of HSP70 and aromatase.

\section{Statistical analyses}

Data are presented as means \pm S.E.M. Statistical significance was analyzed using a one-way ANOVA of variance with post hoc Dunnett's test (SAS Inst. Inc., Cary, NC, USA). Significant differences were set at $P<0.05\left(^{*}\right)$. In Exp. 1, data are expressed as the means from 6 replicates of control and heat-stressed mice.

\section{Results}

Exp. 1

The effects of chronic heat stress on the serum estradiol, granulosa cell apoptosis and folliclular atresia in mouse ovaries are showed in Figs. 1 and 2. As shown in Fig. 1a, the body weights of heat-stressed mice decreased $(P<$ 0.05 ) after 7, 14, 21 or $28 \mathrm{~d}$ of treatment compared with control mice. With increasing time on experiment, the body weights of control mice increased but the body weights of heat-stressed mice did not. Food intake was 


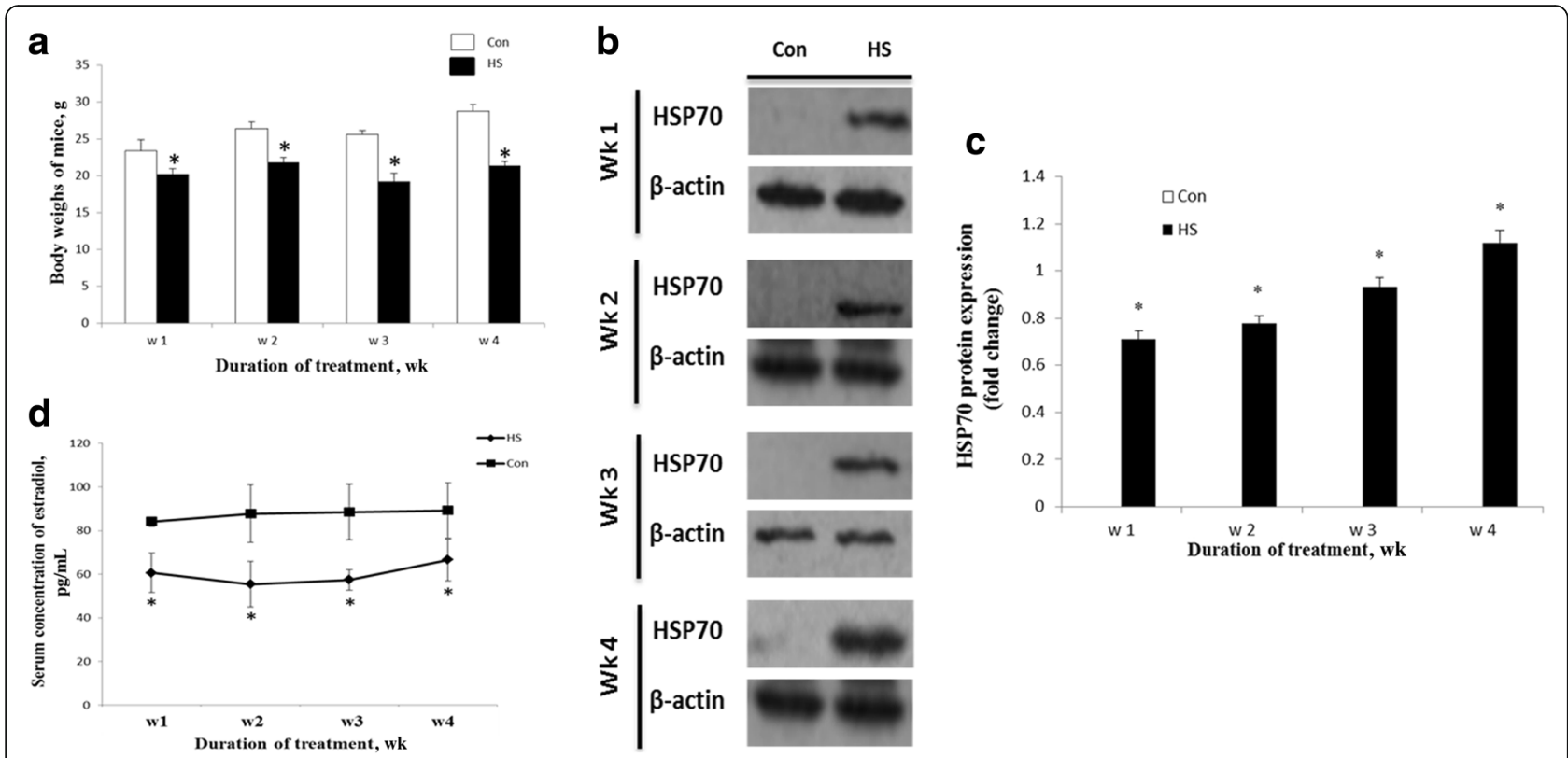

Fig. 1 a Effects of chronic heat stress on body weights, ovarian HSP70 level and serum estradiol concentration. Effects of heat stress on body weights of control and heat-stressed female mice. $\mathbf{b}$ and $\mathbf{c}$ Expression of HSP70 in ovaries of control (Con) and heat-stressed (HS) mice. HSP70 was detected in the lysates of ovaries of mice after each wk of treatment by Western Blot. $\beta$-actin was used as a reference. $\mathbf{d}$ Concentrations of estradiol in serum of heat-stressed mice from $d 7$ to 28 of treatment. ${ }^{*}$, indicates $P<0.05$ compared with the control

also reduced in mice after $21 \mathrm{~d}$ of heat stress (data not shown).

The Western Blot results showed that HSP70 was not expressed in the ovary of control mice. However, HSP70 was highly expressed in the ovary of heat-stressed mice 7, 14, 21 or $28 \mathrm{~d}$ after treatment (Fig. $1 \mathrm{~b}$ and c). The concentration of estradiol in serum decreased $(P<0.05)$ after 7, 14, 21 and $28 \mathrm{~d}$ of heat stress (Fig. 1d). The effects of heat stress on apoptosis of granulosa cells in antral follicles after $21 \mathrm{~d}$ of treatment are illustrated in Fig. $2 \mathrm{a}$ and $\mathrm{b}$. TUNEL showed that there was no difference in the number of antral follicles with mild or moderate apoptotic signals between the control and heat stress mice. However, the number of antral follicles with severe apoptotic signals increased $(P<0.05)$ in the heat stress mice compared with the control mice (Fig. 2b).

The percentage of atretic follicles relative to all antral follicles is illustrated in Fig. 2c and d. The percentage of atretic follicles in the antral follicles of the heat stress mice was greater $(P<0.05)$ than for control mice $21 \mathrm{~d}$ after initiation of treatments (Fig. 2c).

Exp. 2

The effects of heat stress on the abundance of HSP70 and aromatase for in vitro cultured antral follicles are shown in Fig. 3a and b. HSP70 was not expressed in the follicles of control mice. However, HSP70 was highly expressed in the follicles of heat-stressed mice. The expression of aromatase in heat-stressed mice was also decreased $(P<0.05)$ compared with the control mice.

Exp. 3

The effects of heat stress on apoptosis of granulosa cells in ovaries are shown in Fig. 4. The ovaries were exposed to temperatures of 37 or $41{ }^{\circ} \mathrm{C}$ in a water bath for $2 \mathrm{~h}$ and then granulosa cells were harvested and cultured for another $24 \mathrm{~h}$. Compared with the control mice, granulosa cells of the heat-stressed mice had a slower rate of growth after heat stress and an increase in apoptosis compared with granulosa cells from control mice (Fig. 4a). Trypan Blue staining was used to verify granulosa cell viability. The percentage of positive granulosa cells from heat-stressed ovaries was greater $(P<0.05)$ than for granulosa cells from control ovaries (Fig. 4b).

The effects of heat stress on the abundance of different proteins in granulosa cells of heat- stressed mice are shown in Fig. 4c. After ovaries were incubated for $2 \mathrm{~h}$ at $37^{\circ} \mathrm{C}$ or $41{ }^{\circ} \mathrm{C}$, there were no differences in Bim, caspase- 3 or cleaved caspase 3 proteins in granulosa cells (Fig. 4d). The HSP70 level increased in granulosa cells (Fig. 4d). However, $24 \mathrm{~h}$ after treatment, the abundance of HSP70 $(P<0.05)$, Bim $(P<0.05)$ and cleaved caspase $3(P<0.05)$ proteins increased in granulosa cells from ovaries subjected to $41^{\circ} \mathrm{C}$ compared to $37^{\circ} \mathrm{C}$ while the abundance of caspase- 3 decreased $(P<0.05$; Fig. $4 \mathrm{e})$. 


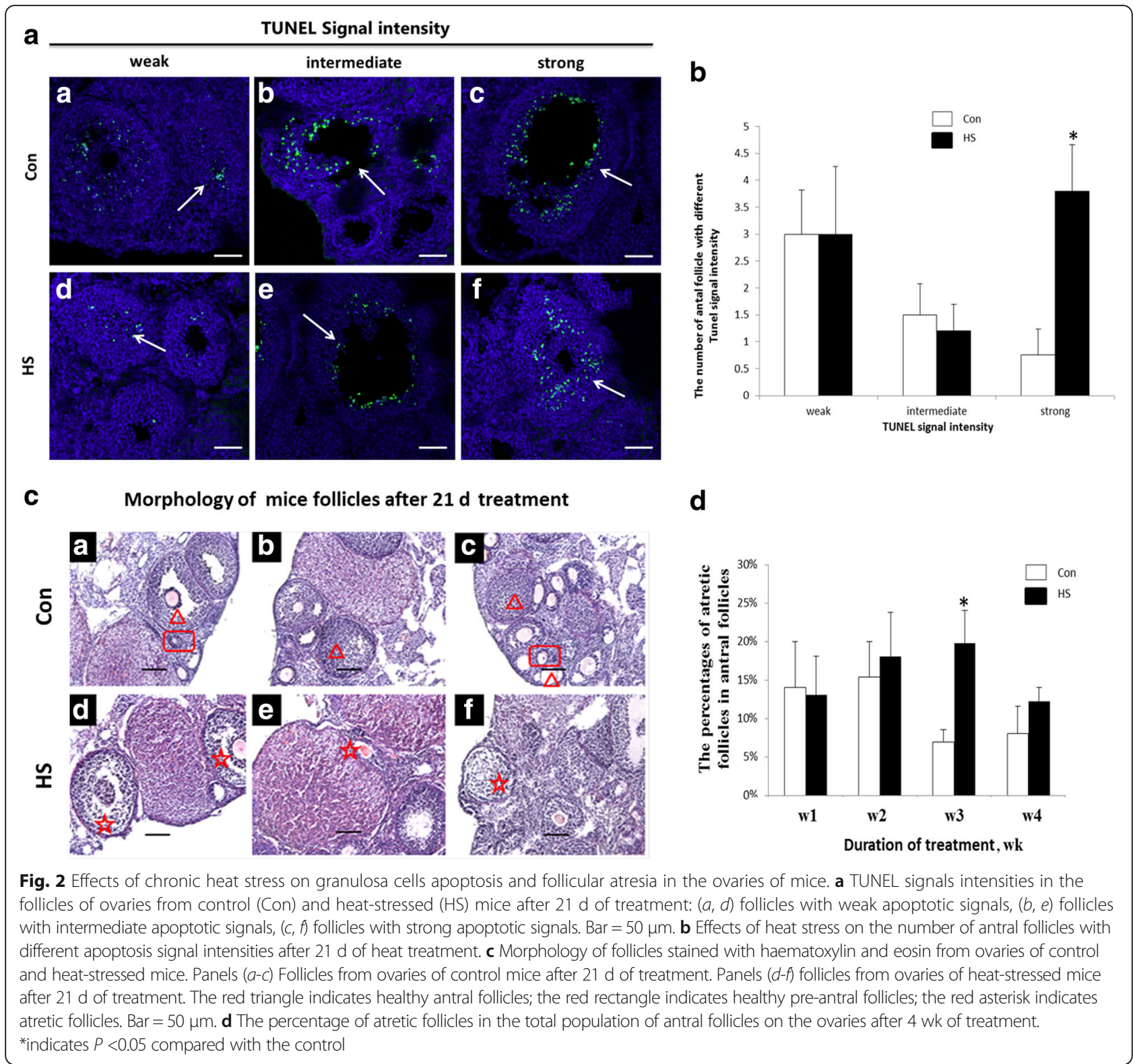

\section{Discussion}

Our results illustrated that chronic heat stress reduced concentrations of estradiol in serum and increased apoptosis of granulosa cells and follicle atresia. Our results also indicated that caspase- 3 and Bim are involved in the heat stress-induced apoptosis of granulosa cells.

Causes of reduced fertility during the summer include changes in follicular dynamics and steroidogenic activity $[1,3]$, lower oocyte competence $[5,6]$, a reduction in the expression of estrus [31] and early embryonic death [32, 33]. To our knowledge, there are no studies reporting changes in the serum estradiol, granulosa cell apoptosis and follicular atresia after chronic heat stress.

In this study, we observed a significant reduction in body weight and food intake in mice (data not shown) after $21 \mathrm{~d}$ of heat stress, which was indicative of reduced energy intake and a nutritional imbalance. Previous studies have indicated that nutrition has an important influence on reproductive function [34, 35]. Acute nutrient restriction reduced the size of the dominant follicle, and resulted in the absence of a pre-ovulatory increase in estradiol and the ovulatory surge of $\mathrm{LH}$, resulting in ovulatory failure in beef heifers [36]. On the other hand, a short period of improved nutrition can stimulate ovulation rate in sheep [37]. For example, lupin grain supplements fed to ewes for 4 to $6 \mathrm{~d}$ before luteolysis increased the ovulation rate [37]. In the present study, we observed an increase in follicular atresia after $21 \mathrm{~d}$ of heat stress. Therefore, the indirect effects of low energy and a nutritional imbalance cannot be ignored compared 


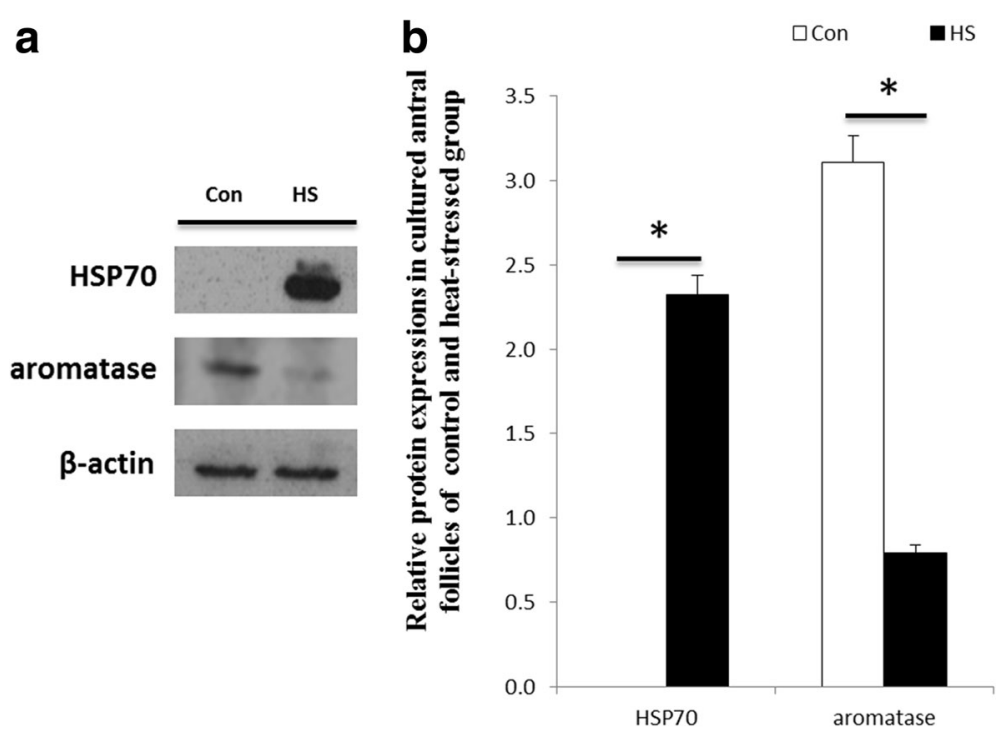

Fig. 3 Effects of heat stress on expression of HSP70 and aromatase in cultured antral follicles obtained from mice. a Effect of heat stress on the expression of HSP70 and aromatase in cultured antral follicles. Antral follicles were cultured at 37 (Con) or $42{ }^{\circ} \mathrm{C}(\mathrm{HS})$ for $24 \mathrm{~h}$. $\mathrm{HSP70}$ and aromatase proteins were analyzed by Western Blotting. b Relative abundance of HSP70 and aromatase proteins in antral follicles cultured at 37 (Con) or $42^{\circ} \mathrm{C}$ (HS) for $24 \mathrm{~h}$. Proteins were normalized with $\beta$-actin. *indicates $P<0.05$ compared with the control

with the direct effects of heat stress on follicular function.

Our results showed that the inducible HSP70 were increased in the ovaries of mice after 7, 14, 21 and $28 \mathrm{~d}$ of heat stress, in cultured follicles after $24 \mathrm{~h}$ of heat stress, and in cultured granulosa cells from ovaries after $2 \mathrm{~h}$ of heat stress. These findings confirm the results of studies using porcine ovaries [38, 39] and Chinese hamster ovary cells [40]. It is suggested that the induction of HSP70 in ovary cells under heat stress is a protective mechanism. HSP70, the major heat stress-inducible protein, protects cells from heat stress-induced apoptosis and affects the apoptotic pathway at the levels of both Cytochrome $\mathrm{C}$ release and initiator caspase activation [41]. In the present study, there were increases in the apoptosis of granulosa cells from ovarian follicles of 21$\mathrm{d}$ heat-stressed mice and heat stressed ovaries. We suggest that the induction of HSP70 occurs to reduce apoptosis of granulosa cells induced by heat stress.

It has been reported that acute heat stress decreased the concentrations of estradiol in serum and follicular fluid in cattle [42-45] and goats [1]. In the present study, serum concentrations of estradiol were significantly decreased after 7, 14, 21 and $28 \mathrm{~d}$ of heat stress. The decrease in serum estradiol could be related to the significant decrease in estradiol concentration in the fluid of follicles and reflect a decrease in the steroidogenic capacities of the follicular cells caused by heat stress. Estrogen production is stimulated by the binding of FSH to its receptors on the granulosa cell membrane which activates the aromatase enzyme that converts testosterone to estradiol $[46,47]$. It is reported that heat stress inhibits the expression of gonadotropin receptors in granulosa cells [3]. In our study, the abundance of aromatase in cultured follicles decreased after heat stress. The decreases in aromatase activity and estradiol concentrations are in agreement with a previous report that the estradiol concentration and aromatase activity in the dominant follicle in cattle are significantly lower in the summer than in the autumn [14]. Therefore, we suggest that heat stress decreases gonadotropin receptor expression and aromatase activity, suppresses estradiol synthesis in estrogenic follicles and induces a decrease in the production of estradiol.

In the present study, heat stress for $21 \mathrm{~d}$ significantly increased the number of apoptotic granulosa cells and there was an increase in the apoptosis of cultured granulosa cells from follicles incubated at $41{ }^{\circ} \mathrm{C}$ for $2 \mathrm{~h}$ compared with control follicles. These results are in agreement with those in previous studies showing that heat stress induced apoptosis in granulosa cells incubated at 40 or $43{ }^{\circ} \mathrm{C}$ in mice and sheep $[4,21]$, as well as in granulosa cells from heatstressed follicles harvested $48 \mathrm{~h}$ after PMSG injection in rats [3]. Therefore, it is suggested that heat stress induced ovarian granulosa cells apoptosis. Our data also indicates that atresia of antral follicles increases after $21 \mathrm{~d}$ of heat stress in mice. These results are in agreement with those in previous studies showing that heat stress during follicular recruitment suppresses subsequent follicle growth to ovulation [1] and reduces the size of the dominant follicle by $\mathrm{d} 8$ in cattle [14] and between d 11 and 21 of the estrous cycle in cows and heifers $[44,45]$. It is suggested that heat stress 


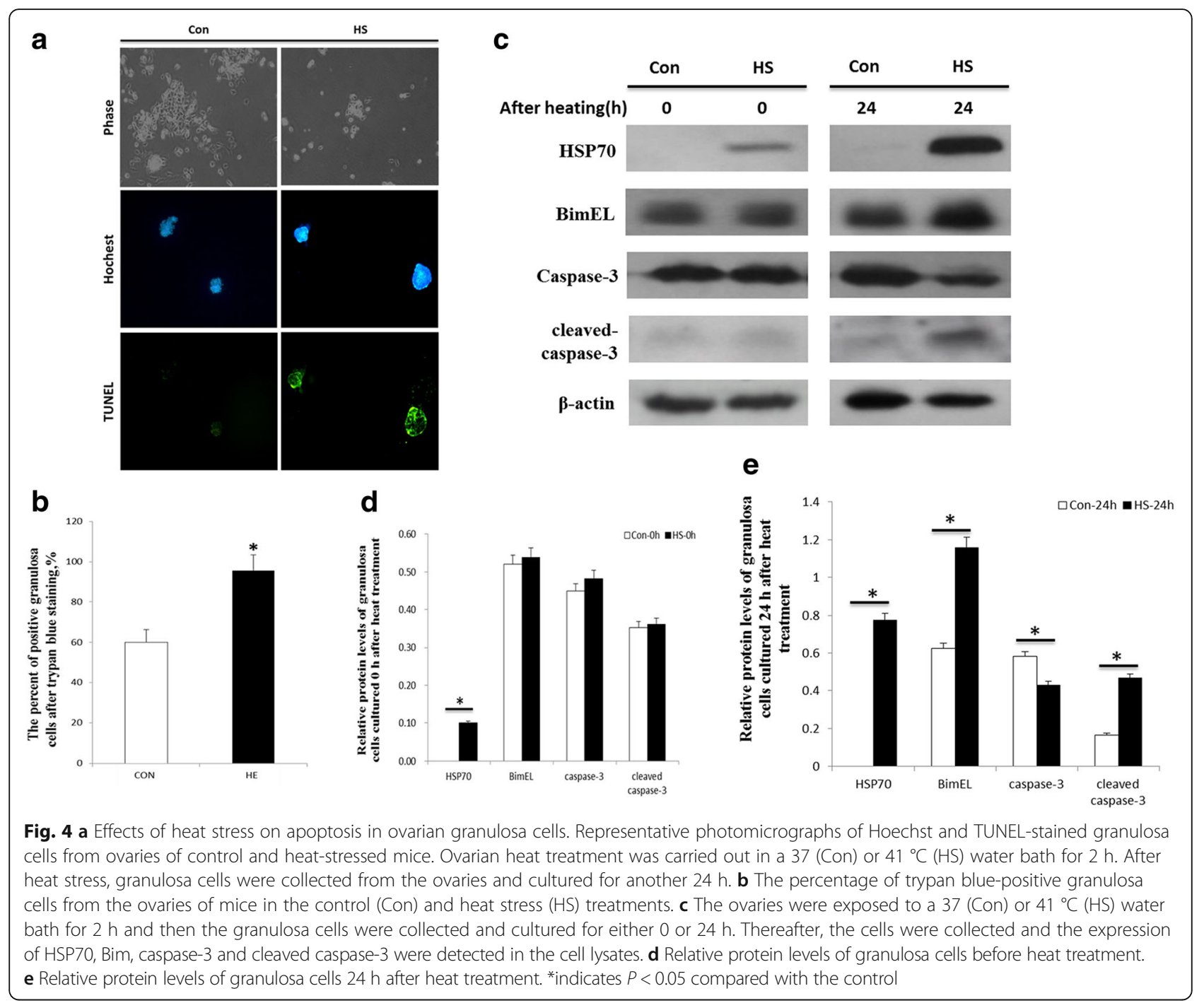

compromises follicular development and promotes antral follicle atresia.

How exactly heat stress induces granulosa cell apoptosis and impacts follicular development is not well understood. One mechanism may be a decrease in the production of estradiol. Granulosa cell apoptosis results from the lack of survival factors such as estradiol [12, 13]. Estrogens inhibit ovarian granulosa cell apoptosis in early antral and pre-antral follicles [12] and estradiol inhibits the activation of endogenous endonucleases and promotes the division and growth of granulosa cells [48]. Therefore, the increase in granulosa cell apoptosis after heat stress may be induced by a decrease in estradiol production. On the other hand, estrogen is essential for folliculogenesis beyond the antral stage of development, as studies with estrogen receptor knockout and estrogen-depleted mice have shown [49]. A rapid decline of estradiol in plasma is an early sign of atresia in antral follicles [50] but most follicles do not reach the ovulatory stage and instead become atretic owing to apoptosis of the granulosa cell lining [25, 51]. Therefore, it is suggested that heat stress decreases estradiol production, enhances susceptibility to apoptosis of granulosa cells and causes antral follicle atresia.

Our findings indicate that the expression of caspase-3, cleaved caspase- 3 and Bim in granulosa cells was similar in the two treatments at the start of the experiment. HSP70 was not expressed in granulosa cells from control ovaries but increased in granulosa cells from heatstressed ovaries. Our results indicate that it takes more than $2 \mathrm{~h}$ for caspase- 3 and Bim to respond to heat stress. After culturing granulosa cells for $24 \mathrm{~h}$, the abundance of HSP70, cleaved caspase- 3 and Bim increased, but caspase-3 decreased in the heat-stressed treatment. In addition, there was a significant increase in apoptosis of granulosa cells in the heat-stressed treatment compared with control mice. We suggest that the pro-apoptotic protein Bim and apoptosis executor caspase-3 are 
connected with heat-induced apoptosis of granulosa cells, and the decrease in the caspase- 3 level and the increase in the cleaved caspase- 3 level may be due to the conversion of caspase- 3 to cleaved caspase- 3 .

The molecular mechanism of heat shock-induced apoptosis of granulosa cells is not clear. Previous studies have indicated that heat-induced apoptosis of mouse granulosa cells via the mitochondrial pathway involves caspase-3 [21], and that the mRNA levels of Bim and caspase- 3 increase in atretic follicles from porcine ovaries [52]. It has also been proposed that Bim is essential to heat shock-induced cell death which induces mitochondrial outer membrane permeabilization and the loss of mitochondrial inner membrane potential in a BAX/ BAK-dependent manner that is antagonized by antiapoptotic BCL-2 family members in MEFs and human Jurkat $\mathrm{T}$ cells [53]. In addition, cells utilize various BH3only family members to integrate a variety of cellular stressors, all of which induce mitochondrial outer membrane permeabilization, apoptosome assembly, caspase activation, and cell death [54]. Furthermore, the increase in Bim observed in the present study may mediate heat shock-induced apoptosis of granulosa cells, and induce mitochondrial outer membrane permeabilization, apoptosome assembly and caspase activation. Whether Bim mediates heat shock-induced apoptosis through a BAX/ BAK-dependent pathway that is antagonized by antiapoptotic BCL-2 family members in heat stress-induced apoptosis of granulosa cells should be explored in the future.

\section{Conclusion}

In conclusion, chronic heat stress reduced the concentrations of estradiol in serum and increased apoptosis of granulosa cells and follicle atresia. Caspase-3 and Bim were involved in the heat stress-induced apoptosis of granulosa cells. Moreover, it is likely that reduced energy intake and a nutritional imbalance as a consequence of reduced food intake contributed to chronic heat stressinduced ovarian dysfunction. Further studies are needed to explain the precise mechanisms for these findings.

\section{Acknowledgements \\ Thanks the funding of the Specialized Research Fund for the Doctoral \\ Program of Higher Education (20130008130001) to support this study.}

\section{Funding}

The design of the study and collection, analysis, and interpretation of data and in writing the manuscript were supported by the Specialized Research Fund for the Doctoral Program of Higher Education (20130008130001).

Availability of data and material

Not applicable

\section{Authors' contributions}

SMZ provided essential experiment conditions and instruments. SMZ, YW, ZT and JYL conceived and designed the experimental plan. JYL, ZT, YF, YZW, LL and $\mathrm{YH}$ performed the experiment. JYL, YW and SMZ analyzed the data and interpreted the results. JYL drafted this manuscript, and HG, SSW and IH made a revision of this manuscript. JYL and ZT participated in feeding mice and collecting samples. All authors read and approved the final manuscript.

Competing interests

The authors declare that they have no competing interests.

\section{Consent for publication}

Not applicable

\section{Ethics approval and consent to participate}

The use of animals reviewed and approved by the Institutional Animal Care and Use Committee at Peking University (Beijing, China) or by the Institutional Animal Care and Use Committee at China Agricultural University (Beijing, China).

\section{Author details}

'Laboratory of Animal Embryonic Biotechnology; National Engineering Laboratory for Animal Breeding; Key Laboratory of Animal Genetics, Breeding, and Reproduction of the Ministry of Agriculture, College of Animal Science and Technology, China Agricultural University, Beijing 100193, China. ${ }^{2}$ State Key Laboratory of Reproductive Biology, Institute of Zoology, Chinese Academy of Sciences, Beijing 100101, China.

Received: 10 April 2016 Accepted: 13 September 2016

Published online: 29 September 2016

\section{References}

1. Ozawa M, Tabayashi D, Latief TA, Shimizu T, Oshima I, Kanai Y. Alterations in follicular dynamics and steroidogenic abilities induced by heat stress during follicular recruitment in goats. Reproduction. 2005;129(5):621-30.

2. Wolfenson D, Roth Z, Meidan R. Impaired reproduction in heat-stressed cattle: basic and applied aspects. Anim Reprod Sci. 2000;60-61:535-47.

3. Shimizu T, Ohshima I, Ozawa M, Takahashi S, Tajima A, Shiota M, et al. Heat stress diminishes gonadotropin receptor expression and enhances susceptibility to apoptosis of rat granulosa cells. Reproduction. 2005;129(4):463-72.

4. Fu Y, He CJ, Ji PY, Zhuo ZY, Tian XZ, Wang F, et al. Effects of melatonin on the proliferation and apoptosis of sheep granulosa cells under thermal stress. Int J Mol Sci. 2014;15(11):21090-104.

5. Banerjee Mustafi S, Chakraborty PK, Dey RS, Raha S. Heat stress upregulates chaperone heat shock protein 70 and antioxidant manganese superoxide dismutase through reactive oxygen species (ROS), p38MAPK, and Akt. Cell Stress Chaperones. 2009;14(6):579-89. doi:10.1007/s12192-009-0109-x. Epub 2009 Mar 17.

6. Cui MS, Fan YP, Wu Y, Hao ZD, Liu S, Chen XJ, et al. Porcine cumulus cell influences ooplasmic mitochondria-lipid distributions, GSH-ATP contents and calcium release pattern after electro-activation. Theriogenology. 2009; 71(3):412-21.

7. Lindquist S. The heat-shock response. Annu Rev Biochem. 1986;55:1151-91.

8. Tissières A, Mitchell HK, Tracy UM. Protein synthesis in salivary glands of Drosophila melanogaster: relation to chromosome puffs. J Mol Biol. 1974; 84(3):389-98.

9. Rockett JC, Mapp FL, Garges JB, Luft JC, Mori C, Dix DJ. Effects of hyperthermia on spermatogenesis, apoptosis, gene expression, and fertility in adult male mice. Biol Reprod. 2001;65(1):229-39.

10. Rosenfeld CS, Wagner JS, Roberts RM, Lubahn DB. Intraovarian actions of oestrogen. Reproduction. 2001;122(2):215-26.

11. Bayne $\mathrm{S}$, Li H, Jones ME, Pinto AR, van Sinderen M, Drummond $A$, et al. Estrogen deficiency reversibly induces telomere shortening in mouse granulosa cells and ovarian aging in vivo. Protein Cell. 2011;2(4):333-46.

12. Billig H, Furuta I, Hsueh AJ. Estrogens inhibit and androgens enhance ovarian granulosa cell apoptosis. Endocrinology. 1993;133(5):2204-12.

13. Chun SY, Eisenhauer KM, Minami S, Billig H, Perlas E, Hsueh AJ. Hormonal regulation of apoptosis in early antral follicles: follicle-stimulating hormone as a major survival factor. Endocrinology. 1996;137(4):1447-56.

14. Badinga $L$, Thatcher WW, Diaz T, Drost M, Wolfenson D. Effect of environmental heat stress on follicular development and steroidogenesis in lactating Holstein cows. Theriogenology. 1993;39(4):797-810.

15. Luo M, Li L, Xiao C, Sun Y, Wang GL. Heat stress impairs mice granulosa cell function by diminishing steroids production and inducing apoptosis. Mol 
Cell Biochem. 2016;412(1-2):81-90. doi:10.1007/s11010-015-2610-0. Epub 2015 Nov 25.

16. Wang SJ, Liu WJ, Wu CJ, Ma FH, Ahmad S, Liu BR, et al. Melatonin suppresses apoptosis and stimulates progesterone production by bovine granulosa cells via its receptors (MT1 and MT2). Theriogenology. 2012;78(7): 1517-26. doi:10.1016/j.theriogenology.2012.06.019.

17. Matsuda F, Inoue N, Manabe N, Ohkura S. Follicular growth and atresia in mammalian ovaries: regulation by survival and death of granulosa cells. J Reprod Dev. 2012;58(1):44-50.

18. Jancar N, Kopitar AN, Ihan A, Virant Klun I, Bokal EV. Effect of apoptosis and reactive oxygen species production in human granulosa cells on oocyte fertilization and blastocyst development. J Assist Reprod Genet. 2007;24(23):91-7. Epub 2007 Jan 11.

19. Palumbo A, Yeh J. In situ localization of apoptosis in the rat ovary during follicular atresia. Biol Reprod. 1994:51(5):888-95.

20. Cory S, Adams JM. The BCl2 family: regulators of the cellular life-or-death switch. Nat Rev Cancer. 2002;2(9):647-56.

21. Chen JZ, Ji CN, Gu SH, Li JX, Zhao EP, Huang Y, et al. Over-expression of Bim alpha3, a novel isoform of human Bim, result in cell apoptosis. Int J Biochem Cell Biol. 2004;36(8):1554-61.

22. Markström E, Svensson EC, Shao R, Svanberg B, Billig H. Survival factors regulating ovarian apoptosis - dependence on follicle differentiation. Reproduction. 2002;123(1):23-30.

23. Riedl SJ, Shi Y. Molecular mechanisms of caspase regulation during apoptosis. Nat Rev Mol Cell Biol. 2004:5(11):897-907.

24. Sudo H, Minami A. Regulation of apoptosis in nucleus pulposus cells by optimized exogenous Bcl-2 overexpression. J Orthop Res. 2010;28(12):1608-13. doi:10.1002/jor.21185.

25. Kaipia A, Hsueh AJ. Regulation of ovarian follicle atresia. Annu Rev Physiol. 1997;59:349-63.

26. Leo CP, Hsu SY, Chun SY, Bae HW, Hsueh AJ. Characterization of the antiapoptotic BCl-2 family member myeloid cell leukemia-1 (Mcl-1) and the stimulation of its message by gonadotropins in the rat ovary. Endocrinology. 1999;140(12):5469-77.

27. Hsu SY, Lin P, Hsueh AJ. BOD (BCl-2-related ovarian death gene) is an ovarian $\mathrm{BH}$ domain-containing proapoptotic $\mathrm{Bcl}-2$ protein capable of dimerization with diverse antiapoptotic BCl-2 members. Mol Endocrinol. 1998;12(9):1432-40.

28. O'Reilly LA, Cullen L, Visvader J, Lindeman GJ, Print C, Bath ML, et al. The proapoptotic BH3-only protein bim is expressed in hematopoietic, epithelial, neuronal, and germ cells. Am J Pathol. 2000;157(2):449-61.

29. Wang XL, Wu Y, Tan LB, Tian Z, Liu JH, Zhu DS, et al. Follicle-stimulating hormone regulates pro-apoptotic protein $\mathrm{BCl}$-2-interacting mediator of cell death-extra long (BimEL)-induced porcine granulosa cell apoptosis. J Biol Chem. 2012;287(13):10166-77. doi:10.1074/jbc.M111.293274. Epub 2012 Jan 10.

30. Shikanov A, Xu M, Woodruff TK, Shea LD. A method for ovarian follicle encapsulation and culture in a proteolytically degradable 3 dimensional system. J Vis Exp. 2011;(49). doi: 10.3791/2695.

31. Hansen PJ, Aréchiga CF. Strategies for managing reproduction in the heatstressed dairy cow. J Anim Sci. 1999;77 Suppl 2:36-50.

32. Ealy $A D$, Drost $M$, Hansen PJ. Developmental changes in embryonic resistance to adverse effects of maternal heat stress in cows. J Dairy Sci. 1993;76(10):2899-905

33. Ozawa M, Hirabayashi M, Kanai Y. Developmental competence and oxidative state of mouse zygotes heat-stressed maternally or in vitro. Reproduction. 2002;124(5):683-9.

34. Evans JJ, Anderson GM. Balancing ovulation and anovulation: integration of the reproductive and energy balance axes by neuropeptides. Hum Reprod Update. 2012;18(3):313-32. doi:10.1093/humupd/dms004. Epub 2012 Mar 22.

35. Bossis I, Wettemann RP, Welty SD, Vizcarra JA, Spicer LJ, Diskin MG. Nutritionally induced anovulation in beef heifers: ovarian and endocrine function preceding cessation of ovulation. J Anim Sci. 1999:77(6):1536-46.

36. Lents CA, White FJ, Ciccioli NH, Floyd-White LN, Rubio I, Keisler DH, et al. Metabolic status, gonadotropin secretion, and ovarian function during acute nutrient restriction of beef heifers. J Anim Sci. 2013;91(9):4146-57. Epub $2013 \mathrm{Jul} 3$.

37. Downing JA, Joss J, Connell P, Scaramuzzi RJ. Ovulation rate and the concentrations of gonadotrophic and metabolic hormones in ewes fed lupin grain. J Reprod Fertil. 1995;103(1):137-45.
38. Sirotkin AV, Bauer M. Heat shock proteins in porcine ovary: synthesis, accumulation and regulation by stress and hormones. Cell Stress Chaperones. 2011;16(4):379-87. doi:10.1007/s12192-010-0252-4. Epub 2010 Dec 28.

39. Pennarossa G, Maffei S, Rahman MM, Berruti G, Brevini TA, Gandolfi F. Characterization of the constitutive pig ovary heat shock chaperone machinery and its response to acute thermal stress or to seasonal variations. Biol Reprod. 2012;87(5):119. doi:10.1095/biolreprod.112.104018.

40. Li GC, Petersen NS, Mitchell HK. Induced thermal tolerance and heat shock protein synthesis in Chinese hamster ovary cells. Int J Radiat Oncol Biol Phys. 1982;8(1):63-7.

41. Mosser DD, Caron AW, Bourget L, Meriin AB, Sherman MY, Morimoto Rl, et al. The chaperone function of hsp70 is required for protection against stress-induced apoptosis. Mol Cell Biol. 2000;20(19):7146-59.

42. Wolfenson D, Thatcher WW, Badinga L, Savio JD, Meidan R, Lew BJ, et al. Effect of heat stress on follicular development during the estrous cycle in lactating dairy cattle. Biol Reprod. 1995;52(5):1106-13.

43. Wolfenson D, Lew BJ, Thatcher WW, Graber Y, Meidan R. Seasonal and acute heat stress effects on steroid production by dominant follicles in cows. Anim Reprod Sci. 1997:47(1-2):9-19.

44. Wilson SJ, Kirby CJ, Koenigsfeld AT, Keisler DH, Lucy MC. Effects of controlled heat stress on ovarian function of dairy cattle. 2. Heifers. J Dairy Sci. 1998:81(8):2132-8.

45. Wilson SJ, Marion RS, Spain JN, Spiers DE, Keisler DH, Lucy MC. Effects of controlled heat stress on ovarian function of dairy cattle. 1. Lactating cows. J Dairy Sci. 1998;81(8):2124-31.

46. Dorrington JH, Moon YS, Armstrong DT. Estradiol-17beta biosynthesis in cultured granulosa cells from hypophysectomized immature rats; stimulation by follicle-stimulating hormone. Endocrinology. 1975;97(5):1328-31.

47. Erickson GF, Hsueh AJ. Stimulation of aromatase activity by follicle stimulating hormone in rat granulosa cells in vivo and in vitro. Endocrinology. 1978;102(4):1275-82.

48. Chaube SK, Prasad PV, Thakur SC, Shrivastav TG. Estradiol protects clomiphene citrate-induced apoptosis in ovarian follicular cells and ovulated cumulus-oocyte complexes. Fertil Steril. 2005;84 Suppl 2:1163-72.

49. Drummond AE, Findlay JK. The role of estrogen in folliculogenesis. Mol Cell Endocrinol. 1999;151(1-2):57-64.

50. Otsuka M, Kishi H, Arai K, Watanabe G, Taya K, Greenwald GS. Temporal changes in inhibin, steroid hormones, and steroidogenic enzymes during induced follicular atresia in the hypophysectomized cyclic hamster. Biol Reprod. 1997;56(2):423-9.

51. Amsterdam A, Gold RS, Hosokawa K, Yoshida Y, Sasson R, Jung Y, et al. Crosstalk among multiple signaling pathways controlling ovarian cell death. Trends Endocrinol Metab. 1999;10(7):255-62.

52. Fu Y, Lin $\mathrm{F}$, Liu H. Changes in the messenger RNA expression levels of $\mathrm{BCl}-2$ family members and caspase- 8 and -3 in porcine ovarian follicles during follicular atresia. Anim Sci J. 2013;84(3):222-30. doi:10.1111/j.1740-0929.2012. 01061.x. Epub 2012 Sep 21.

53. Mahajan IM, Chen MD, Muro I, Robertson JD, Wright CW, Bratton SB. BH3only protein BIM mediates heat shock-induced apoptosis. PLoS One. 2014; 9(1):e84388. doi:10.1371/journal.pone.0084388. eCollection 2014.

54. Bratton SB, Cohen GM. Apoptotic death sensor: an organelle's alter ego? Trends Pharmacol Sci. 2001;22(6):306-15.

\section{Submit your next manuscript to BioMed Central and we will help you at every step:}

- We accept pre-submission inquiries

- Our selector tool helps you to find the most relevant journal

- We provide round the clock customer support

- Convenient online submission

- Thorough peer review

- Inclusion in PubMed and all major indexing services

- Maximum visibility for your research

Submit your manuscript at www.biomedcentral.com/submit 